\title{
Property Rights, Tax Avoidance and Capital Structure: Data from China Stock Markets
}

\author{
Pei Wang ${ }^{1}$, Kun Guo ${ }^{2}$, Dan Ding ${ }^{3} \&$ Shuyi $\mathrm{Li}^{1}$ \\ ${ }^{1}$ School of Business Administration, China University of Petroleum-Beijing, Beijing, China \\ ${ }^{2}$ China Civil Engineering Construction Corporation, Beijing, China \\ ${ }^{3}$ China Petroleum Finance Co.LTD, Beijing, China \\ Correspondence: Pei Wang, School of Business Administration, China University of Petroleum-Beijing, Beijing \\ 102249, China. Tel: 138-1093-6549. E-mail: peggie_wang@126.com
}

Received: August 30, 2018

Accepted: October 11, 2018

Online Published: October 20, 2018

doi:10.5539/ijef.v10n11p13

URL: https://doi.org/10.5539/ijef.v10n11p13

Fund project: This paper is a phased research results of "Construction and Application of Performance Evaluation System of State-Owned Enterprises Under the New Normal Economy (ZX20150129)"sponsored by "Excellent Young Teachers of China University of Petroleum (Beijing)".

\begin{abstract}
This paper investigates the influence of tax avoidance on capital structure based on share ownership under China's economic system. Previous research has indicated that tax avoidance exits and has a potential effect on firms' capital structure, but there is little literature focusing on this influence based on China's economic system. In light of that, this paper uses A-share data of the Shanghai and Shenzhen stock exchange from 2007 to 2016 as samples to study the impact of tax avoidance on the capital structure based on China's economic system. The results suggest that, firstly, there is a significant negative correlation between tax avoidance and the debt ratio of the listed companies; secondly, there is a significant difference in the effect of corporate tax avoidance on the debt ratio of different industries and different equity ownership. Besides, by regrouping the samples according to the share ownership and the degree of tax avoidance, it is revealed that China's unique economic system would lead to an impact of tax avoidance on the capital structure that differs from other countries. Finally, it is found that there is a negative correlation between the degree of tax avoidance of the listed companies and the dynamic adjustment of assets-liability ratio through the extended study, further verifying that there is a substitution relationship between tax avoidance of the listed companies and their debt financing.
\end{abstract}

Keywords: tax avoidance, capital structure, trade-off theory, China's economic system

\section{Introduction}

As an important branch of corporate finance theory, capital structure has long been the concern of many scholars. Modigliani and Miller (1963) further developed the MM model in the case of tax and pointed out that the tax-shield effect of liabilities could reduce the total cost of capital and increase the value of an enterprise when the corporate income tax was taken into consideration, which laid the theoretical foundation for studying the impact of tax on the corporate capital structure.

Tax avoidance is a way for an enterprise to reduce its tax burden and increase its value by reducing the shares of the third party (government) in the profitability of the enterprise. DeAngelo and Masulis (1980) found that firms with a large number of non-debt tax shields (ie tax shield effects through accounting bookkeeping, etc.) tended to favor using non-debt tax shields rather than debt tax shields. To a certain extent, this explained the "low debt problem of enterprises" discovered by Miller (1977) and Graham (2000), that is, the enterprises having less debt financing than theory. Graham and Tucker (2006) argued that corporate tax avoidance activities have a substitution effect on debt financing, further illustrating the impact of tax avoidance on the corporate capital structure. After 40 years' rapid development in China's reform and opening up, China's capital market has become more rationalized in its financing methods and capital structure. Against the background of China's economic system, it is necessary to study the role of tax avoidance in China's enterprises and its impact on corporate debt financing and capital structure. 
This paper studies the A-share listed companies in China to solve the following four problems. Firstly, to verify whether tax avoidance has an impact on the capital structure of enterprises under the special institutional background in China; secondly, to analyze whether the government's tax reform will affect the extent of corporate tax avoidance and affect the corporate capital structure; Thirdly, to test the existence of differences in the tax avoidance's effect for enterprises with different share ownership and corporate capital structure; Fourthly, to explore the possible relationship between the dynamic adjustment of corporate capital structure and tax avoidance.

\section{Literature Review and Hypotheses}

\subsection{Literature Review}

Tax avoidance came along with the establishment of the private company system. Although many scholars have conducted extensive research into corporate tax avoidance, there has been no uniformly accepted concept so far. Plesko (1999) argued that tax avoidance was the difference between the actual tax burden on a firm and the statutory tax burden that the firm should bear under the tax regime. Dyreng et al. (2008) defined tax avoidance as all the transactions or events that led to the reduction of the actual tax burden on the enterprise. Hanlon and Heitzman (2010) defined tax avoidance as everything that firms could do to reduce tax or to claim tax incentives. Lanis and Richardson (2011) emphasized that tax avoidance was a tax-planning activity limited to tax law, and its purpose was to increase the cash holdings of enterprises by reducing the tax burden on enterprises. Some scholars believed that corporate tax avoidance was a form of long-term tax-planning based on the strategic developmental goals of the enterprise. And it was closely related to the stage reached by the enterprise and its long-term strategy (Dyreng et al., 2008; Zhaoguo et al., 2015). It is normally assumed that tax avoidance is a strategy which could reduce the firm's explicit taxes (Bill et al., 2016; Hope et al., 2013; Hasan et al., 2014).

Traditional trade-off theory pointed out that, because of the existing costs of financial distress, enterprises would project a 'trade off' between the benefits of tax shield of debt and the financial distress caused by debt, and then decide the optimal capital structure of the enterprise. However, Miller (1977) and Warner (1977) found that the majority of firms appeared to have lower bankruptcy costs due to non-debt tax shields related to the tax shields generated by the liabilities of the listed public corporations in the United States. This hypothesis has been further extended and validated using empirical methods by Brennan and Schwartz (1984), Kane et al. (1984) and Graham (2000). When DeAngelo and Masulis (1980) conducted research into corporate finance strategy, they found that corporate tax avoidance and its debt financing had an alternative role. Enterprises could also use non-debt tax shields, such as depreciation provision and accounting for investment income to achieve the effect of debt tax shield, reducing the demand for debt financing.

However, Bradley et al. (1984) found that there was an anomalous positive correlation between the extent of corporate tax avoidance and the amount of debt financing. This may be because Bradley used only corporate depreciation in the study as proxy variable to measure the degree of tax avoidance so they did not fully reflect the level of corporate tax avoidance. Dan et al. (1992) think that the smaller the effective tax rate, the lower the corresponding corporate debt level, which showed that the corporate tax avoidance was negatively correlated with the debt level. Slemrod (2004) and Crocker et al. (2005) observing the tax avoidance management risk and non-tax bankruptcy costs of enterprises, pointed out that enterprises would control their level of debt to a certain extent and thus reduce their asset-liability ratio from the perspective of risk management. Ishii (2014) studied the relationship between corporate loan costs and tax avoidance and found that banks regarded enterprise corporate tax avoidance activities as a risk factor, which would increase the costs of the enterprise's debt and affect its corporate capital structure. Due to the complexity of reality, some scholars hold other views. Hamid et al. (2018) using the data on Chinese listed firms, found tax avoidance to be positively associated with bank loans and loan costs but negatively correlated with loan terms. This result may arise from raised financing costs imposed by Chinese banks on companies which show tax avoidance behavior. Christopher et al. (2015) found no relation between various corporate governance mechanisms and tax avoidance.

Among scholars in China, Xianzhong (2001) proposed the conceptual framework between the corporate capital structure and tax revenue and further discussed the relationship between corporate capital structure and corporate tax burden. Surong (2005) verified the applicability of tax-based MM theory in China's capital market through case studies. Yi (2011) elaborated the relationship between capital structure and tax avoidance of listed companies in China's capital market by studying the non-debt tax shield and the capital structure of listed companies in China. Tingting (2012) discussed the correlation between corporate debt financing and tax avoidance from the perspective of the weakening of corporate capital, and pointed out that enterprises inclined to a higher level of tax avoidance tended to have a lower level of debt financing. Gang (2013), from the perspective 
of debt contract analysis, found that having the same conditions in other aspects, the higher the degree of tax avoidance, the higher the cash holdings and the lower the possibility of debt default, which would reduce an enterprise's debt financing costs in the debt market and increase the company's asset-liability ratio. From the perspective of principal-agent theory, Tong et al. (2015) found corporate tax avoidance had an impact on the cost of corporate debt financing, and further found that corporate tax avoidance activities would, to some extent, increase the debt financing costs of enterprises. Da (2016) basing his argument on the theory of tax avoidance agency, put forward the finding that corporate tax avoidance is negatively correlated with debt ratio and the relation between these two will be affected by corporate governance.

\subsection{Hypotheses}

According to trade-off theory, the enterprise value could be divided into three parts: the value of non-debt-bearing enterprise with the same value of equity, the present value of tax shield due to liability and the present value of the bankruptcy cost of the enterprise. Using tax avoidance activities of enterprises to replace corporate liabilities could not only achieve the effect of tax-shield, but could also effectively avoid the risk of debt default and bankruptcy costs brought by debt financing. DeAngelo and Masulis (1980), Bradley et al. (1984), Dan et al. (1992), Slemrod (2004) and Crocker et al. (2005) found that there was a certain substitution effect between corporate tax avoidance and its debt financing. In other words, tax avoidance could achieve the same effect as a tax-shield caused by corporate debt financing andcould reduce the costs of financial distress.

These arguments lead to the following hypothesis:

Hypothesis I: Firms with higher level of tax avoidance tend to have lower level of debt ratio.

Due to the differences in market types, scale of enterprises, growth of enterprises, profitability of enterprises and taxation policies of industries, there were certain differences in the risks and benefits of the activities for enterprises in different industries. Correspondingly, there was difference in degrees of tax avoidance. Tax avoidance would also have different impacts on the capital structure of enterprises. Yu-Bao and Jia-Yu (2013) found that there were some differences between the actual tax burden and the nominal tax burden of oil and gas enterprises in the study of the actual tax burden of the oil and gas industry. This is mainly because most of the oil and gas industries are monopoly industries, which have strong scale effect and high profitability. Besides, the nominal tax rate is relatively higher, so oil and gas industries have a strong incentive to conduct tax evasion activities, and the degree of tax avoidance compared to other industries will be higher. However, for some industries where the market competition is fierce and the average profit rate is low, the difference between nominal tax and actual tax burden is not obvious. In addition, taking into account the risks that enterprises need to bear when tax avoidance occurs and the tax revenue, firms' motivation to conduct tax avoidance is not too strong and their level of corporate tax avoidance is relatively lower. Xinhao (2017) studied the relationship among manufacturing enterprises' tax policies, profitability levels and actual tax burden and found that there was scarcely any difference between the actual tax burden and the nominal tax burden in the manufacturing industry. In the course of the study, Hou also found that, due to the different profitability and preferential tax policies, there were also some differences in motivation of tax evasion in different manufacturing industries. On the basis of the differences in tax evasion in the industry, Shao-shai (2011), Yi (2011) and Qiang (2016) also found that there were some differences in the degree of tax avoidance among listed companies in different industries in China. These arguments lead to the following hypothesis:

Hypothesis II: Firms in different industries have different levels of tax avoidance and the impact of firms in different industries on their debt ratio is different.

Due to the special institutional background of China, the demands of state-owned and non-state-owned listed companies for taxation and debt are significantly different. The performance evaluation index of state-owned listed companies is not only related to the level of profitability but also has a close relationship with the amount of tax paid. Therefore, the motivation for tax avoidance will be weaker. In addition, compared to non-state-owned enterprises, state-owned enterprises are more likely to obtain loans from financial institutions such as banks and their motivation for conducting tax avoidance activities is also relatively weaker. In the analysis of the correlation between the "origin" of listed companies and corporate tax avoidance activities, Wei (2011) used the actual controller of the enterprise as a variable of company origin and found that the degree of tax avoidance in private enterprises was more serious than in state-owned listed companies. Therefore, the last hypothesis can also be stated as follows:

Hypothesis III: Firms with different property rights have different degrees of tax avoidance and the impact of firms with different share ownership on their debt ratio is different. 


\section{Research Methodology}

\subsection{Measure of Variables}

The specific choice of agency variable of enterprise capital structure depends on the research direction and purpose and the main topic of this paper is the impact of tax avoidance activities on the corporate capital structure. Drawing on related studies from scholars like Brennan and Schwartz (1984), Kane et al. (1984), Graham (2000), Slemrod (2004) and Sun Gang (2013) and Jinzhi et al. (2015), the asset-liability ratio is used as the proxy variable to measure the corporate capital structure.

As a measure of tax avoidance, this article uses the difference between the nominal income tax rate of the current year and the current ETR as the proxy variable to measure the level of corporate tax avoidance. In addition, in order to further verify the robustness of the empirical results, this article also draws on Frank et al. (2009) in the study of corporate tax avoidance and corporate capital structure for corporate tax avoidance measurement method. The residual term that cannot be explained by the variable - DTAX serves as a proxy for the degree of corporate tax avoidance, so that the robustness of the model can be tested.

At the same time, based on previous literature, this article also selected the scale of enterprises, the growth of enterprises, the profitability of enterprises, the guarantee value of tangible assets of enterprises, the investment level of enterprises, the cost of market financing, the degree of share ownership of enterprises, the factors of corporate governance, share ownership and industries as control variables. The main variables are listed in Table 1Appropriate identification of research participants is critical to the science and practice of psychology, particularly for generalizing the findings, making comparisons across replications, and using the evidence in research syntheses and secondary data analyses. If humans participated in the study, report the eligibility and exclusion criteria, including any restrictions based on demographic characteristics.

Table 1. Variables in model

\begin{tabular}{|c|c|c|}
\hline Name & Proxy varibles & Definition \\
\hline Capital structure (LEV) & Debt ratio (LA) & Liability/assets \\
\hline \multirow{2}{*}{ Level of tax avoidance $(\mathrm{T})$} & ETR & $\begin{array}{l}\text { Current nominal tax rate-Current income tax charge contributions } \\
\text { / Earnings before interest and tax for the current period }\end{array}$ \\
\hline & DTAX & $\begin{array}{l}\text { ETR differential } \times \text { pre-tax accounting profits }=\mathbf{a}+\mathbf{b} \times \text { controls }+\mathbf{e} \text {, in } \\
\text { which e is DTAX }\end{array}$ \\
\hline Size(A) & $\operatorname{Ln}($ asset) & LN(assets) \\
\hline Growth $(G)$ & $\mathrm{PE}$ ratio(G) & Price/Earning \\
\hline Profitability(RC) & ROA & Income/Asset \\
\hline Collateral Value of Assets(M) & $\begin{array}{l}\text { Proportion of tangible assets in } \\
\text { total assets }(M)\end{array}$ & $($ Inventory + fixed assets)/assets \\
\hline Investment(I) & Growth rate of fixed assets(I) & $\begin{array}{c}\text { (Fixed assets fixed assets this year - last year ) / fixed assets last } \\
\text { year }\end{array}$ \\
\hline Financing $\operatorname{cost}(\mathrm{FC})$ & Tobin's Q & Book value /market value \\
\hline $\begin{array}{l}\text { Share ownership } \\
\text { concentration(EC) }\end{array}$ & Top3hold & The top three holding equit / total equity of the company \\
\hline Corporate governance factors(MA) & Managerial share ownership & Managerial share ownership \\
\hline Share ownership $(O)$ & $\begin{array}{l}\text { Share ownership of listed } \\
\text { companies }\end{array}$ & State-owned $=1 /$ otherwise $=0$ \\
\hline Industry(IN) & Industry code of 2008 & Industry code of 2008 \\
\hline
\end{tabular}

\subsection{Selection of Data}

This paper chooses the relevant data of CSMAR of A-share listed companies in Shanghai and Shenzhen from 2007 to 2016, excluding ST, * ST and PT listed companies and financial listed, after screening, we get 12939 observations as the final sample data.

\subsection{Empirical Models}

This article draws on Frank et al.'s (2009) method of classifying corporate tax avoidance into Discretionary tax sheltering items and Non-discretionary tax sheltering items, and adopts an effective tax rate ETR differential and DTAX to measure the degree of corporate tax avoidance.

$$
\begin{gathered}
\operatorname{ETRDIFF}_{\mathrm{i}, \mathrm{t}}=\operatorname{ETR}_{i, t} \times \operatorname{EBIT}_{\mathrm{i}, \mathrm{t}}-\operatorname{Tax}_{\mathrm{i}, \mathrm{t}} \\
\operatorname{ETRDIFF}_{\mathrm{i}, \mathrm{t}}=\alpha+\alpha_{1} \times \operatorname{Intag}_{\mathrm{i}, \mathrm{t}}+\alpha_{2} \times M I_{i, t}+\alpha_{3} \times T_{i, t}+\alpha_{4} \mathrm{ETRDIFF}_{\mathrm{i}, \mathrm{t}-1}+\varepsilon_{\mathrm{i}, \mathrm{t}}
\end{gathered}
$$




$$
\operatorname{DTAX}_{i, t}=\frac{\varepsilon_{\mathrm{i}, \mathrm{t}}}{E B I T_{i, t}}
$$

ETRDIFFi in model 2, $\mathrm{t}$ denotes the degree of tax avoidance in year $\mathrm{t}$ of enterprise $\mathrm{i}$ under the effective tax rate method, ETRi, $t$ denotes the degree of tax avoidance in year $t$ of enterprise $i$ under the effective tax rate method, EBITi, $t$ denotes the profit before tax of enterprise $i$ in year $t$, Taxi, $t$ represents the income tax expense of enterprise $\mathrm{i}$ in year $\mathrm{t}$; in model 3, Intagi, $\mathrm{t}$ represents the net intangible assets of enterprise $\mathrm{i}$ in year $\mathrm{t}, \mathrm{MIi}, \mathrm{t}$ represents the profit and loss of minority $i$ in year $t$ of enterprise $i$, TIi, $t$ represents $i$ enterprise The t-year pre-tax accounting profit, ETRDIFFi, $t-1$ represents the $\mathrm{t}-1$ year under the effective tax rate method of enterprise tax accounting, residual error $\varepsilon i$, $t$ that tax difference under the law i enterprises $t$ tax scale; In model 4, DTAXi, $t$ represents the degree of tax avoidance in year $t$ of $i$ firm under the law of tax difference.

In order to further verify the robustness of the results, this paper uses Current ETR as a measure of robustness. Current ETR refers to the ratio of the current tax payment to the current EBIT. Under the effective tax rate method, Enterprise Tax Evasion (ETR) measures the difference between the nominal income tax rate of the enterprise and the current effective tax rate (Current ETR) as shown in Model 4:

$$
T E R_{i, \mathrm{t}}=T A X_{\mathrm{i}, \mathrm{t}}-\frac{I T_{i, t}}{E B I T_{i, t}}
$$

Where ETRi, $t$ represents the degree of tax avoidance of enterprise $i$ in year $t$, TAXi, $t$ represents the nominal income tax rate of enterprise $\mathrm{i}$ in year $\mathrm{t}$, and IT represents the income tax expense of enterprise $\mathrm{i}$ in year $\mathrm{t}, \mathrm{EBIT}$, $t$ represents enterprise $i$ in year $t$ EBIT profits.

For the study of tax avoidance and capital structure of listed companies, this paper draws on the practice of Yang Li-bin et al. (2007) and Harrington (2012) as shown in model 5:

$$
L E V_{i, t}=\beta_{0}+\beta_{1} T_{i, t}+\sum_{j=2}^{10} \beta_{j} \operatorname{control}_{j, i, t}+\mu_{i, t}
$$

$\mathrm{LEVi}, \mathrm{t}$ represents the debt-to-asset ratio of enterprise $\mathrm{i}$ in year $\mathrm{t}, \mathrm{Ti}, \mathrm{t}$ represents the degree of tax avoidance in enterprise $i$ in year $i$, controli, $t$ represents the corresponding control variable of enterprise $i$ in Table 1 , and $\mu \mathrm{i}, t$ represents the residual error of regression.

\section{Results}

\subsection{Sample Description}

Table 2. Sample description

\begin{tabular}{cccccc}
\hline Variables & Max & Min & Mean & Median & St \\
\hline LA & 0.975 & 0.046 & 0.456 & 0.457 & 0.225 \\
ETR & 0.270 & -0.230 & 0.022 & 0.007 & 0.118 \\
DTAX & 4.470 & -2.389 & 0.033 & -0.023 & 0.719 \\
A & 26.326 & 19.232 & 21.811 & 21.642 & 1.295 \\
G & 965.965 & -210.17 & 71.291 & 35.097 & 145.672 \\
ROA & 0.204 & -0.201 & 0.039 & 0.036 & 0.056 \\
M & 0.837 & 0.010 & 0.401 & 0.395 & 0.190 \\
I & 1.697 & -0.867 & -0.077 & -0.047 & 0.315 \\
TOBINQ & 10.656 & 0.166 & 2.083 & 1.566 & 1.831 \\
EC & 85.809 & 15.253 & 48.621 & 48.398 & 15.941 \\
MA & 0.665 & 0 & 0.078 & 0 & 0.167 \\
O & 1 & 0 & 0.212 & 0 & 0.409 \\
\hline
\end{tabular}

As Table 2 shows, the average debt-to-asset ratio of listed companies is 0.456 and the median is 0.457 . The median and the mean of debt-to-asset ratio differ by 0.001 and the standard deviation of debt-to-asset ratio is 0.225 , indicating that the presentation of sample data of company's assets and liabilities follows the normal distribution. The mean values of the tax avoidance of the sample companies under the effective tax rate method and the sample tax difference method are both positive, indicating that there is tax avoidance behaviour in the sample companies. In addition, the mean value of tax avoidance (ETR) under the effective tax rate method is 0.022 with a median of 0.007 , indicating a positive skewed distribution of sample companies' tax avoidance under the effective tax rate method. The degree of sample companies' tax avoidance is generally small, which is consistent with the distribution of the tax avoidance degree of the sample companies under the tax differential 
method. The standard deviation of the indicators of growth $(\mathrm{G})$ and the equity concentration (EC) of the sample companies are greater than 10 , indicating that the sample companies' $\mathrm{P} / \mathrm{E}$ ratio and the shareholding of the top three shareholders have relatively larger fluctuations.

\subsection{Correlation Analyses}

In order to further determine the correlation between the selected variables, the spearman correlation test is conducted, and the test results are shown in Table 3.

Table 3. Spearman test

\begin{tabular}{|c|c|c|c|c|c|c|c|c|c|c|c|}
\hline & LA & ETR & DTAX & A & $\mathrm{G}$ & ROA & $\mathrm{M}$ & $\mathrm{I}$ & TOBINQ & EC & MA \\
\hline LA & 1.00 & & & & & & & & & & \\
\hline ETR & -0.01 & 1.00 & & & & & & & & & \\
\hline DTAX & -0.17 & 0.31 & 1.00 & & & & & & & & \\
\hline A & 0.44 & -0.10 & 0.21 & 1.00 & & & & & & & \\
\hline G & -0.17 & -0.24 & -0.17 & -0.30 & 1.00 & & & & & & \\
\hline ROA & -0.46 & -0.04 & -0.06 & -0.04 & -0.17 & 1.00 & & & & & \\
\hline M & 0.38 & -0.01 & 0.05 & 0.16 & -0.07 & -0.27 & 1.00 & & & & \\
\hline I & 0.14 & 0.03 & 0.00 & -0.04 & -0.02 & -0.23 & 0.21 & 1.00 & & & \\
\hline TOBINQ & -0.55 & 0.09 & -0.09 & -0.63 & 0.33 & 0.42 & -0.29 & -0.08 & 1.00 & & \\
\hline $\mathrm{EC}$ & -0.11 & -0.05 & -0.02 & 0.15 & -0.08 & 0.22 & -0.04 & -0.15 & -0.01 & 1.00 & \\
\hline MA & -0.37 & -0.06 & -0.10 & -0.21 & 0.06 & 0.22 & -0.23 & -0.20 & 0.19 & 0.06 & 1.00 \\
\hline
\end{tabular}

It could be seen from Table 3 that both the corporate tax avoidance measured by the effective tax rate method and the degree of tax avoidance measured by the tax differential method are negatively correlated with the debt-to-asset ratio of the sample companies, which guarantees the correctness of model hypothesis I.

To further test whether there is multiple co-linearity among the variables, the variance expansion factor analysis is conducted, and the results are shown in Table 4 and Table 5.

Table 4. VIF based on ETR

\begin{tabular}{ccc}
\hline Var & VIF & $1 / \mathrm{VIF}$ \\
\hline ETR & 1.170 & 0.852 \\
TOBINQ & 1.660 & 0.604 \\
A & 1.560 & 0.642 \\
ROA & 1.310 & 0.762 \\
MA & 1.230 & 0.813 \\
M & 1.170 & 0.853 \\
G & 1.170 & 0.858 \\
EC & 1.130 & 0.886 \\
I & 1.090 & 0.919 \\
O & 1.080 & 0.928 \\
\hline Mean & 1.260 &
\end{tabular}

Table 5. VIF based on DATX

\begin{tabular}{ccc}
\hline Var & VIF & $1 /$ VIF \\
\hline DTAX & 1.020 & 0.978 \\
TOBINQ & 1.590 & 0.631 \\
A & 1.570 & 0.637 \\
ROA & 1.240 & 0.804 \\
MA & 1.230 & 0.814 \\
M & 1.180 & 0.851 \\
G & 1.060 & 0.939 \\
EC & 1.130 & 0.883 \\
I & 1.090 & 0.918 \\
O & 1.080 & 0.926 \\
\hline Mean & 1.220 & \\
\hline
\end{tabular}


Multi- co-linearity must satisfy the condition that the maximum value of VIF is greater than 10 . As can be seen from Table 4 and Table 5, VIF of all variables is less than 10. That is, there is no multiple co-linearity in the sample data.

\subsection{Differences Analyses}

\subsubsection{Industrial Difference Analysis}

In order to further analyze the differences in the degree of tax avoidance of the sample data of listed companies in different industries, this paper uses the method of one-factor analysis of variance and the results are shown in Table 6.

Table 6. One-factor analysis of variance for industry difference

\begin{tabular}{ccccccc}
\hline \multicolumn{7}{c}{ One-factor analysis of variance } \\
\hline Source & BS & Based on ETR & MS & Based on DTAX \\
Between groups & 0.226 & 16.540 & 0.000 & 0.968 & 1.880 & 0.014 \\
Within groups & 0.014 & & & 0.516 & & \\
\hline
\end{tabular}

As Table 6 shows, the variance between groups based on the tax difference method is 17.416, the variance within the group is 5219.305 , and the F value of the industry difference test is 1.880 . This shows that there is industry divergence at the 5\% significance level for the degree of tax avoidance of sample companies based on the DTAX method.

Based on the above analysis, we can see that for the sample companies, there is a significant level of 5\% when it comes to industry differences in the degree of tax avoidance.

\subsubsection{Share Ownership Difference Analysis}

Table 7. One-factor analysis of variance for share ownership difference

\begin{tabular}{ccccccc}
\hline \multicolumn{7}{c}{ One-factor analysis of variance } \\
\hline Source & BS & F & Prob $>$ F & MS & Based on DTAX \\
Between groups & 0.010 & 7.093 & 0.000 & 0.968 & 1.880 & 0.014 \\
Within groups & 0.001 & & & 0.516 & & \\
\hline
\end{tabular}

As could be seen from Table 7, the results of robustness test using the tax difference method show that the degree of tax avoidance of sample companies with different shareholdings is different in terms of $1 \%$ significant level.

\subsection{Regression Analyses}

Table 8. The regression results of whole sample

\begin{tabular}{ccc}
\hline VAR & Based on ETR & Based on DTAX \\
\hline T & $-0.013^{*}$ & $-0.010^{* * *}$ \\
A & $0.065^{* * *}$ & $0.064^{* * *}$ \\
G & $0.000^{* *}(1)$ & $0.000^{*}(2)$ \\
ROA & $-1.295^{* * *}$ & $-1.268^{* * *}$ \\
M & $0.208^{* * *}$ & $0.226^{* * *}$ \\
I & 0.001 & 0.004 \\
TOBINQ & $-0.003^{* * *}$ & -0.002 \\
EC & $-0.001 * * *$ & $-0.001^{* * *}$ \\
MA & $-0.240^{* * *}$ & $-0.255^{* * *}$ \\
OS & $0.010^{* * *}$ & $0.009^{* *}$ \\
cons & -0.903 & -0.904 \\
Adj R-squared & 0.442 & 0.445 \\
\hline
\end{tabular}

Note. ***, **, * present the level of significance of $1 \%, 5 \%$ and $10 \%$ respectively.

(1)-0.0000241; (2)-0.0000238. 
Table 8 shows the multiple regression results of the sample companies based on effective tax rate method and the tax rate difference method (LA) on corporate tax avoidance. From the multiple regression results of asset-liability ratio and tax avoidance of listed companies, it could be seen that both the ETR and DTAX are negatively related to company's debt-to-asset ratio at $10 \%$. The coefficients of corporate tax avoidance based on ETR regression and DTAX regression are -0.013 and -0.010 , respectively. This shows that, as the sample company's tax avoidance increases by $1 \%$, the company's debt-equity ratio decreases by $0.013 \%$ and $0.010 \%$, which is consistent with the content of hypothesis I. At the same time, the regression coefficients of the proxy variable OS, which indicates the nature of the firm's equity, are 0.010 and 0.009 , respectively, under the two different kinds of measures of tax avoidance, which indicates that the share ownership of the sample company is also one of the factors that affect its capital structure. Under the same conditions, the debt-to-asset ratio of state-owned listed companies under two different kinds of measures of tax avoidance is higher than that in the non-state-owned listed companies.

In order to further illustrate that the tax avoidance of listed companies in different industries has different impact on the capital structure, this paper uses model (2) to conduct multiple linear regression. Model (2) sets the industry dummy and tax based on model (1) Avoidance of interactive items.

$$
L E V_{\mathrm{i}, t}=\beta_{0}+\beta_{1} T_{i, t}+\sum \beta_{j} \operatorname{control}_{j, i, t}+\sum \operatorname{Ind}_{\mathrm{i}, t} * T_{i, t}+\mu_{i, t}
$$

Table 9. The regression results based on model (2)

\begin{tabular}{|c|c|c|}
\hline VAR & Based on ETR & Based on DTAX \\
\hline $\mathrm{T}$ & $-0.023 *$ & $0.011 * * *$ \\
\hline A & $0.060 * * *$ & $0.060 * * *$ \\
\hline G & $0.000^{* *}(1)$ & $0.000^{* *}(2)$ \\
\hline ROA & $-1.262 * * *$ & $-1.233 * * *$ \\
\hline M & $0.226^{* * *}$ & $0.244 * * *$ \\
\hline I & 0.001 & 0.003 \\
\hline TOBINQ & $-0.003 * * *$ & $-0.002 *$ \\
\hline $\mathrm{EC}$ & $-0.001 * * *$ & $-0.001^{* * * *}$ \\
\hline MA & $-0.239 * * *$ & $-0.254 * * *$ \\
\hline OS & $0.011 * * *$ & $0.010 * *$ \\
\hline $\mathrm{B} * \mathrm{~T}$ & 0.095 & 0.134 \\
\hline $\mathrm{C} * \mathrm{~T}$ & 0.075 & $0.045^{* *}$ \\
\hline $\mathrm{D} * \mathrm{~T}$ & -0.080 & -0.099 \\
\hline $\mathrm{E}^{*} \mathrm{~T}$ & $-0.330 * * *$ & $-0.399 * * *$ \\
\hline $\mathrm{F}^{*} \mathrm{~T}$ & $-0.054 *$ & $-0.075^{*}$ \\
\hline $\mathrm{G}^{*} \mathrm{~T}$ & $-0.223 * *$ & $-0.279 * *$ \\
\hline $\mathrm{H}^{* \mathrm{~T}}$ & $-0.006^{*}$ & -0.273 \\
\hline $\mathrm{K}^{*} \mathrm{~T}$ & $-0.163 * *$ & $-0.253^{* * * *}$ \\
\hline $\mathrm{L}^{*} \mathrm{~T}$ & -0.179 & -0.084 \\
\hline $\mathrm{M} * \mathrm{~T}$ & -0.259 & -0.218 \\
\hline $\mathrm{N} * \mathrm{~T}$ & $-0.196 *$ & $-0.326^{*}$ \\
\hline $\mathrm{O} * \mathrm{~T}$ & -0.570 & $-0.481 *$ \\
\hline $\mathrm{P} * \mathrm{~T}$ & 0.211 & 0.174 \\
\hline $\mathrm{Q} * \mathrm{~T}$ & 0.508 & 0.618 \\
\hline $\mathrm{R} * \mathrm{~T}$ & $0.529 * * *$ & $0.457 * * *$ \\
\hline $\mathrm{S} * \mathrm{~T}$ & -0.064 & $-0.138 *$ \\
\hline _cons & -0.822 & -0.823 \\
\hline Adj R-squared & 0.450 & 0.453 \\
\hline
\end{tabular}

Note. $* * *, * *, *$ present the level of significance of $1 \%, 5 \%$ and $10 \%$ respectively.

(1)-0.0000259; (2)-0.0000281.

From the regression results of model (2), there is a significant difference in the effect of tax avoidance (T) on debt-to-asset ratio of sample companies in different industries. Taking industry $\mathrm{E}$ and industry $\mathrm{F}$ as examples, the regression coefficient of the tax avoidance degree $(\mathrm{T})$ of the industry $\mathrm{E}$ under the effective tax rate method is $-0.353(-(0.023+0.330))$, while the regression coefficient of the industry $\mathrm{F}$ tax avoidance $(\mathrm{T}) 0.077(-(0.023+$ 
0.054)), indicating that the asset-liability ratio (LA) of industry $\mathrm{E}$ and industry F-sample companies changed $-0.353 \%$ and $-0.077 \%$ when the sample company's tax avoidance $(\mathrm{T})$ changed by $1 \%$. There is also a difference in other industries, which is consistent with Hypothesis II. The multiple regression results of the tax difference method also further verify the robustness of the regression results.

In order to further clarify the impact of tax avoidance on the capital structure of listed companies with different equity share ownership in the sample, this paper uses model (3) to conduct multiple linear regression. Model (3) sets dummy variables' interaction with tax avoidance.

$$
L E V_{i, t}=\beta_{0}+\beta_{1} T_{i, t}+\sum \beta_{j} \operatorname{control}_{j, i, t}+\sum O S_{i, t} * T_{i, t}+\mu_{i, t}
$$

Table 10. The regression results based on model (3)

\begin{tabular}{ccc}
\hline VAR & Based on ETR & Based on DTAX \\
\hline ETR & $-0.016^{* * *}$ & $-0.010^{* * *}$ \\
A & $0.065^{* *}$ & $0.064^{*}$ \\
G & $0.000^{* * *(1)}$ & $0.000^{* * *}(2)$ \\
ROA & -1.294 & -1.274 \\
M & 0.208 & 0.226 \\
I & $0.001 * * *$ & $0.004 * * *$ \\
TOBINQ & $-0.003 * * *$ & $-0.002^{* * *}$ \\
EC & $-0.001 * * *$ & $-0.001 * * *$ \\
MA & -0.239 & -0.255 \\
OS & $0.012^{* * *}$ & $0.010^{* * *}$ \\
OS*T & $0.010^{*}$ & $0.002 *$ \\
cons & -0.902 & -0.902 \\
Adj R-squared & 0.442 & 0.445 \\
\hline
\end{tabular}

Note. $* * * * * *$ present the level of significance of $1 \%, 5 \%$ and $10 \%$ respectively.

(1)-0.0000242; (2)-0.0000275.

Table 10 shows the multiple regression results of the degree of tax avoidance and debt-to-asset ratio of sample companies that participate in the interaction between tax avoidance and equity nature. As can be seen from Table 10 , the regression coefficient of state-owned listed companies under the effective tax rate $(\mathrm{T})$ is -0.006 $(-0.016+0.010)$, indicating that the sample is listed in China. When the company's tax avoidance (T) changes by $1 \%$, its asset-liability ratio (LA) will change by $0.6 \%$ in reverse; and for non-state listed companies in the sample, the degree of tax avoidance ( $\mathrm{T}$ ) will affect the asset-liability ratio. The regression coefficient for (LA) is -0.016 . This may be due to the absence of owners of state-owned enterprises under the current national conditions in China, which leads to more prominent agency problems in the management of state-owned enterprises than non-state-owned enterprises. It can be seen from the theoretical framework of the agency that state-owned enterprise managers have increased their free cash for tax avoidance. The use efficiency of the stream is low. That is, the tax shield effect generated by tax avoidance will be relatively reduced, which results in that the regression coefficient of China's listed companies' tax avoidance on asset-liability ratio is relatively small. This difference in the regression results under the actual tax rate method is consistent with the content of Hypothesis III, which shows that the tax evasion activities of different share ownership enterprises have different effects on the capital structure of the company. Similarly, under the method of meeting tax differences, there is also a difference between the degree of tax avoidance $(\mathrm{T})$ of listed companies and non-state listed companies on the ratio of debt to assets (LA), which further ensures the robustness of the regression results.

\section{Extended Study}

\subsection{Group Research}

In order to further discuss the impact of the relationship between the debt ratio and the nature of different equity based on the regression results, this paper divides the sample companies into four groups according to the asset-liability ratio and the nature of the equity to further investigate the regression results, and the results are shown in Table 11: 
Table 11. The regression result based on LA and OS

\begin{tabular}{ccccc}
\hline Based on DTAX & $(1)$ & $(2)$ & $(3)$ & $(4)$ \\
\hline DTAX & $-0.002^{*}$ & $-0.007^{*}$ & $-0.010^{* * * *}$ & $-0.005^{*}$ \\
A & $0.034^{* * *}$ & $0.020^{* * *}$ & $0.027^{* * *}$ & $0.025^{* * *}$ \\
G & $0.000^{* *(1)}$ & $0.000^{*}(2)$ & $0.000(3)$ & $0.000(4)$ \\
ROA & $-0.301^{* * *}$ & $-0.196^{* *}$ & $-0.761^{* * *}$ & $-0.792^{* * *}$ \\
M & $0.202^{* * *}$ & $0.137^{* * *}$ & $0.033^{* * *}$ & $0.058^{* * *}$ \\
I & -0.005 & -0.009 & 0.006 & -0.004 \\
TOBINQ & $-0.004^{* * *}$ & $-0.005^{* *}$ & $0.014^{* * *}$ & 0.001 \\
EC & $-0.001^{* * *}$ & $-0.001^{* * *}$ & 0.000 & $0.000^{* * *}$ \\
MA & $-0.091^{* * *}$ & $-0.369^{* * *}$ & $-0.158^{* * *}$ & -0.265 \\
cons & -0.458 & -0.104 & 0.028 & 0.100 \\
Adj R-squared & 0.288 & 0.132 & 0.169 & 0.170 \\
\hline
\end{tabular}

Note. $* * *, * *$ * present the level of significance of $1 \%, 5 \%$ and $10 \%$ respectively.

(1), (2), (3), (4) represent the low debt ratio \& non-state-share ownership, low debt ratio \& state-share ownership, high debt ratio \& non-state-share ownership, high debt ratio \& state-share ownership, in which 'high debt ratio' refers to a debt ratio higher than the median debt ratio of the sample.

As Table 11 shows when the asset-liability ratio increases, the absolute value of the regression coefficient of listed companies' tax avoidance on the asset-liability ratio increases, that is, the non-debt taxation shield effect generated by tax avoidance is increasing. This may be due to the fact that when the asset-liability ratio of listed companies rises, the controlling power of listed company creditors on listed companies gradually increases and over-investment in listed companies, abuse of power, etc., reduce tax avoidance and generate a non-debt taxation shield effect. Restrictions have been made to increase the non-debt tax shield effect of tax avoidance.

On the other hand, when the listed company's asset-liability ratio is low, the absolute value of the regression coefficient of state-owned listed companies on asset-liability ratios is smaller than that of non-state-listed companies, which is consistent with the empirical results in Table 10. Under the framework of the doctrine of control rights, when the asset-liability ratio of a company is low, the actual control of the enterprise is in the hands of shareholders. Because of the problem of the virtual status of the owners of state-owned enterprises, the agency problem in state-owned enterprises is even more prominent. The non-debt tax shield effect that leads to the tax avoidance of state-owned enterprises is smaller, and the absolute value of the regression coefficient in empirical results is small, when the asset-liability ratio of the listed companies in the sample is high, the actual control right of the listed companies is gradually transferred to the creditors. Although the non-debt tax shield effect of the listed company's tax avoidance has been improved, compared to non-debt state-owned listed companies, banks and other creditors have relatively low governance efficiency for state-owned listed companies in China (Zhengjie, 2011). They have little control over the cash flow generated by tax avoidance. These factors have limited the tax avoidance of the increase of resulting non-debt taxation shield effect caused by tax avoidance in state-owned listed companies and the regression result of measuring the degree of tax avoidance by the effective tax rate method is consistent with the above results.

\subsection{Dynamic Impact Analysis}

In order to further verify the relationship between dynamic adjustment of capital structure and tax avoidance in listed companies, this paper uses model (4) to conduct multiple regression.

$$
\text { ADJLEV } \mathrm{i}_{\mathrm{i}, t}=\beta_{0}+\beta_{1} T_{i, t}+\sum \beta_{j} \operatorname{control}_{j, i, t}+\mu_{i, t}
$$

Table 12. The regression result of capital structure adjustment

\begin{tabular}{ccc}
\hline & ETR & DTAX \\
\hline T & $-0.007 * * *$ & $-0.005^{* * *}$ \\
A & $0.002^{* * *}$ & $0.002^{* * *}$ \\
G & $0.000^{* * * *}$ & $0.000^{* * *}$ \\
ROA & $-0.032^{*}$ & $-0.040^{*}$ \\
M & $0.021^{* *}$ & $0.022^{* *}$ \\
I & $0.035^{* *}$ & $0.035^{* *}$ \\
TOBINQ & $0.003^{* * *}$ & $0.003 * * *$ \\
EC & $0.000^{* * *}$ & $0.000^{* * *}$ \\
MA & $-0.039^{* *}$ & $-0.039^{*}$ \\
OS & $-0.004 * * *$ & $-0.004 * * *$ \\
cons & -0.043 & -0.048 \\
\hline
\end{tabular}


As can be seen from Table 12, under the two methods of measuring tax avoidance, the sample companies' tax avoidance ( $\mathrm{T}$ ) and their dynamic asset-liability ratio adjustment (ADJLEV) are all negatively correlated at the level of $1 \%$. The regression coefficients of the degree of avoidance (T) on ADJLEV are -0.007 and -0.005 respectively, which show that the degree of tax avoidance $(\mathrm{T})$ of sample companies increases by $1 \%$ under the two kinds of measurement of tax avoidance. Asset-liability ratio adjustments decreased by $0.007 \%$ and $0.005 \%$ respectively which further verifies Hypothesis I.

\subsection{Impact of Enterprise Tax Income Reform}

Since the time span of this study includes the tax reform of consolidation of taxes imposed on overseas-funded enterprises and domestic enterprises in 2008, it is necessary to consider whether this tax reform will affect the research conclusion. Firstly, the tax reform reduced the rate of income tax for general resident enterprises from $33 \%$ to $25 \%, 20 \%$ for the non-resident enterprises, $20 \%$ for small enterprises, and $15 \%$ for 'high-tech' enterprises. Thereafter, government has gradually cancelled (2008-2012) the preferential taxation policies for enterprises in the coastal 'special economic zone' and foreign-funded enterprises. Therefore, the data are further grouped into three periods: before the tax reform (2007), transition period (2008-2012) and after the tax reform (2013-2016), and each has a regression analysis.The results are shown in Table 14.

Table 14. The regression results based on different periods

\begin{tabular}{cccc}
\hline Regression coefficient & 2007 & $2008-2012$ & $2012-2016$ \\
\hline ETR & $-0.006 *$ & $-0.004 *$ & -0.014 \\
DTAX & $-0.017 * *$ & $-0.009 * * *$ & $-0.002 * * *$ \\
\hline
\end{tabular}

Note. ***,**, * present the level of significance of $1 \%, 5 \%$ and $10 \%$ respectively.

As is shown in the Table 14, whichever period the data are in, sample firms with higher levels of tax avoidance tend to have lower levels of debt ratio. This conclusion is consistent with the empirical results of Hypothesis I.

The direct effect of the tax reform in 2008 was the change in the rate of enterprise income tax. With elimination of preferential taxation policies, the nominal tax rates fell for most enterprises, while there was a rise in tax rates for the above-mentioned specific companies. In order to further explore the impact of enterprise income tax reform in 2008 on this study, this paper refers to Dan et al. (1992) for their view of enterprise income tax reform in the United States in 1986. On the basis of the model (5), two dummy variables, dummy1 and dummy2, which represent the change of enterprise income tax rate, are added. These two dummy variables represent the changes of the rate of enterprise income tax for sample enterprises from December 31, 2007 to December 31, 2016. Based on the income tax rate of the previous year, the dummy1 will be 1 if the income tax rate goes down, otherwise it will be 0 ; if the income tax rate goes up, the dummy 2 will be 1 , otherwise it will be 0 . This paper uses model (5) to conduct the change in the income tax rates.

Table 15. The regression results based on the change of tax rates

\begin{tabular}{ccc}
\hline VAR & Based on ETR & Based on DTAX \\
\hline T & -0.012 & $-0.010 * * *$ \\
A & $0.066^{* * *}$ & $0.065 * * *$ \\
G & $0.000^{*}$ & $0.000 *$ \\
ROA & $-1.301 * * *$ & $-1.271 * * *$ \\
M & $0.210^{* *}$ & $0.228 * * *$ \\
I & 0.001 & 0.004 \\
TOBINQ & $-0.003 * *$ & -0.002 \\
EC & $-0.001 *$ & $-0.001 * * *$ \\
MA & $-0.244 * * *$ & $-0.258 * * *$ \\
Dummy1 & $-0.014 * * *$ & $-0.006 *$ \\
Dummy2 & $0.023 * * *$ & $0.017 * *$ \\
cons & -0.932 & -0.923 \\
Adj R-squared & 0.443 & 0.445 \\
\hline
\end{tabular}

Note. $* * * * * *$ present the level of significance of $1 \%, 5 \%$ and $10 \%$ respectively. 
It can be seen from Table 15 that there is still a negative correlation between tax avoidance and asset-liability ratio of sample companies after excluding the effect of tax rate change on asset-liability ratio. This finding further verifies Hypothesis I.

\section{Discussion and Conclusion}

\subsection{Conclusions}

This paper centers on the relationship between tax avoidance and the capital structure of listed companies by sample analysis. Three significant major conclusions are drawn as follows.

Firstly, tax avoidance of listed companies has a negative impact on capital structure. Corporate tax avoidance activities can theoretically reduce corporate income tax by reducing their pretax profit. That is, corporate tax avoidance activities and corporate debt financing activities have an alternative role as tax shield and thus affect the capital structure of companies. The regression analysis in this paper shows a negative correlation, which is unaffected by the enterprise income tax reform in 2008, at a significant level of $10 \%$.

Secondly, for enterprises in different industries and with different stock rights, there are significant differences in the impact of tax avoidance on their capital structure. Industrial differences may come from various industrial risks while share ownership differences may result from China's unique institutions.

Last but not least, in extended study, after grouping the sample companies by asset-liability ratio and stock rights, or introducing the adjustment of dynamic asset-liability ratio as a dependent variable, the negative correlation between tax avoidance and capital structure does always exist. The robustness of the conclusions is further verified.

\subsection{Contributions}

Based on the special system background of China, this paper discusses the relationship between it and capital structure from the perspective of tax avoidance. The research results offer enrichment to support capital structure theory.The main contrbutions are as follows. Firstly, by applying One-Factor ANOVA (analysis of variance), we can show that there is a significant difference in the effect of corporate tax avoidance on the debt ratio between enterprises with different industries and different equity ownership. Secondly, the empirical analysis of the relationship between tax avoidance and capital structure are from two dimensions, that is, asset-liability ratio and asset-liability dynamic adjustment ratio of listed companies, making the research results more robust. Thirdly, by regrouping the samples according to the share ownership and the degree of tax avoidance of the listed companies, we have demonstrated that there are significant differences in the influential degree of tax avoidance on the capital structure of listed companies.

\subsection{Suggestions}

From the empirical analyses above, suggestions from three perspectives are put forward below.

As an important constructor of non-debt tax shield, tax avoidance can reduce the outflow of cash and increase the value of enterprises. Tax avoidance can effectively substitute for corporate debt financing which causes bankruptcy risk. However, a corresponding tax risk emerges with increase in value of enterprises, intensifying information asymmetry between managers and stakeholders and volatility of stock price. Therefore, managers should make use of tax avoidance activities appropriately after balancing their pros and cons, simultaneously improving tax planning and financial personnel training.

Enterprise income tax is an important source of government revenue, which supports the smooth operation of society and ensures social welfare. The establishment of a reasonable and effective tax system can promote the development of enterprises as well as increasing government revenues so government should establish a perfect information disclosure system of listed companies to constrain enterprise behavior and ensure the continuity and stability of financial revenue. At the same time, when formulating tax policies, such as tax rates and preferential tax policies, tax policymakers should take into account the nature of the industry and the equity nature of the enterprises so as to avoid a mismatch between the income and the actual tax burden of the enterprise.

Tax avoidance increases the value of enterprises, effectively increasing the returns of external investors but entails tax risks and agency costs, due to agency problems. This paper finds that the transfer of corporate control can significantly affect the non-debt tax shield substitution effect. Therefore, external investors should weigh the advantages and disadvantages of tax avoidance and make rational investment decisions.

\subsection{Limitations}

Based on capital structure theory, this paper has studied the impact of tax avoidance on the capital structure of 
listed companies, through analyzing different industries, property rights and control rights. However, there are two main limitations to this empirical research.

The first is the selection of proxy variables. Although many scholars have made extensive definitions of corporate tax avoidance, so far, there is no unified and widely accepted definition of tax avoidance. In this paper, effective tax rate method and the differences of Tax law and Accounting method calibre inconsistencies are employed to measure corporate tax avoidance but this selection has certain limitations. The effective tax rate is relatively simple and does not take into consideration the impact of corporate deferred tax or the impact of the differences of Tax law and Accounting method's calibre inconsistencies. The method of adjusting these differences in the effective tax rate method, which is currently a commonly used method in the study of tax avoidance, also has some measurement deviation. Further study is needed on effective measurement of the degree of companies' tax avoidancein relation to China's tax environment.

Secondly, during the time-span selected for this paper, the economic environment and tax environment of enterprises have changed. We have attempted corresponding extended studies to alleviate the influence of change, but eliminating the influence of environmental factors on empirical results over a certain time span remains a problem that needs to be solved in future research.

\section{References}

Aghion, P., \& Bolton, P. (1992). An Incomplete Contracts Approach to Financial Contracting. Review of Economic Studies. http://dx.doi.org/10.2307/2297860

Bankman, J. (2004). An academic's view of the tax shelter battle. Crisis in Tax Administration Brookings Institution Press.

Bill, B. F., Ning, R., \& Qiang, W. (2017). Banking deregulation and corporate tax avoidance. China Journal of Accounting Research, 10(02), 87-104.

Bradley, M., Jarrell, G. A., \& Kim, E. H. (1984). On the Existence of an Optimal Capital Structure: Theory and Evidence. The Journal of Finance. http://dx.doi.org/10.1111/j.1540-6261.1984.tb03680.x

Brennan, M. J., \& Schwartz, E. S. (1984). Optimal Financial Policy and Firm Valuation. The Journal of Finance. http://dx.doi.org/10.1111/j.1540-6261.1984.tb03647.x

Chen, K. P. (2005). Internal Control versus External Manipulation: A Model of Corporate Income Tax Evasion. Rand Journal of Economics, 36(1), 151-164.

Christopher, S. A., Jennifer, L. B., Alan, D. J., \& David, F. L. (2015). Corporate governance, incentives, and tax avoidance. Journal of Accounting and Economics, 60(1), 1-17.

Crocker, K. J., \& Slemrod, J. (2005). Corporate tax evasion with agency costs. Journal of Public Economics. http://dx.doi.org/10.1016/j.jpubeco.2004.08.003

$\mathrm{Da}, \mathrm{Y}$. (2016). Research on the Influence of Corporate Tax Avoidance on Capital Structure. Yunnan University.

Dan, G., Hayn, C., Ofer, A. R. et al. (1992). Taxes and Capital Structure: Evidence from Firms' Response to the Tax Reform Act of 1986. Review of Financial Studies, 5(2), 331-355.

Desai, M. A., Dyck, A., \& Zingales, L. (2007). Theft and taxes. Journal of Financial Economics. http://dx.doi.org/10.1016/j.jfineco.2006.05.005

Dyreng, S. D., Hanlon, M., \& Maydew, E. L. (2008). Long-Run Corporate Tax Avoidance. Social Science Electronic Publishing. http://dx.doi.org/10.2308/accr.2008.83.1.61

Feilu, Z., Jie, H., \& Huan, D. (2015). Who's more excessive debt in China: State - owned and non-state - owned enterprises? Economic Research Journal, (12), 54-67.

Frank, M. M., Lynch, L. J., \& Rego, S. O. (2009). Tax Reporting Aggressiveness and Its Relation to Aggressive Financial Reporting. Accounting Review, 84(2), 467-496.

Gang, S. (2013). Taxation Check, Tax avoidance and Debt Financing Costs. Journal of Shanxi Finacne University, 35(3), 78-89.

Graham, J. R. (2000). How Big Are the Tax Benefits of Debt? The Journal of Finance. http://dx.doi.org/10.1111/0022-1082.00277

Graham, J. R., \& Tucker, A. L. (2006). Tax shelters and corporate debt policy. Journal of Financial Economics. http://dx.doi.org/10.1016/j.jfineco.2005.09.002 
Gruber, M. J., \& Warner, J. B. (1997). Bankruptacy Costs: Some Evidence. The Journal of Finance. http://dx.doi.org/10.1111/j.1540-6261.1977.tb03274.x

Hamid, B., Chi, C. C., \& May, H. (2018). Does tax avoidance behavior affect bank loan contracts for Chinese listed firms. International Review of Financial Analysis, (58), 104-116.

Hanlon, M., \& Heitzman, S. (2010). A review of tax research. Journal of Accounting \& Economics. http://dx.doi.org/10.1016/j.jacceco.2010.09.002

Harrington, C., \& Smith, W. (2012). Tax Avoidance and Corporate Capital Structure. Journal of Finance \& Accountancy.

Hasan, I., Hoi, C. K. S., Wu, Q., \& Zhang, H. (2014). Beauty is in the eye of the beholder: The effect of corporate tax avoidance on the cost of bank loans. Journal of Financial Economics. http://dx.doi.org/10.1016/j.jfineco.2014.03.004

Jensen, M. C., \& Meckling, W. H. (1976). Theory of the firm: Managerial behavior, agency costs, and share ownership structure.

Kane, A., Marcus, A. J., \& Mcdonald, R. L. (1984). How Big is the Tax Advantage to Debt? The Journal of Finance. http://dx.doi.org/10.2307/2327948

Kraus, A., \& Litzenberger, R. H. (1973). A State-Preference Model of Optimal Financial Leverage. The Journal of Finance, 28(4), 911-922.

Lanis, R., \& Richardson, G. (2011). The effect of board of director composition on corporate tax aggressiveness. Journal of Accounting \& Public Policy. http://dx.doi.org/10.1016/j.jaccpubpol.2010.09.003

Miller, M. H. (1977). Debt and Taxes. The Journal of Finance. http://dx.doi.org/10.2307/2326758

Myers, S. C., \& Majluf, N. S. (1984). Corporate financing and investment decisions when firms have information that investors do not have. Social Science Electronic Publishing, http://dx.doi.org/10.1016/0304-405X(84)90023-0

Ole-Kristian, H., Mark, M., Thomas, W. B. (2013). Tax avoidance and geographic earnings disclosure. Journal of Financial Economics. http://dx.doi.org/10.1016/j.jacceco.2013.06.001

Phillips, J. D. (2003). Corporate Tax-Planning Effectiveness: The Role of Compensation-Based Incentives. Accounting Review. http://dx.doi.org/10.2308/accr.2003.78.3.847

Plesko, G. A. (1999). Evidence and Theory on Corporate Tax Shelters. National Tax Association, 367-371.

Porcano, T. (1986). Corporate tax rates: Progressive, proportional, or regressive. Journal of the American Taxation Association, 7(2), 17-31.

Rego, S. O. (2003). Tax-Avoidance Activities of U.S. Multinational Corporations. Contemporary Accounting Research. http://dx.doi.org/10.1506/VANN-B7UB-GMFA-9E6W

Robichek, A. A. (1967). Horne J C V. Abandonment Value and Capital Budgeting: Reply. The Journal of Finance, 22(4), 96-97.

Rubinstein, M. E. (1973). Corporate Financial Policy in Segmented Securities Markets. Journal of Financial and Quantitative Analysis. http://dx.doi.org/10.2307/2329980

Slemrod, J. B. (2004). The Economics of Corporate Tax Selfishness. National Tax Journal, http://dx.doi.org/10.17310/ntj.2004.4.06

Surong, W.(2005). Analysis of Correlation between Capital Structure and Taxation. Taxation Research, (10), $18-20$.

Tingting, Z. (2012). The Research on Tax Law's Regulation of Thin Capitalization. Jilin University.

Wei, L., \& Yiping, C. (2017). A study on the adjustment of corporate capital structure based on cash flow. Friends of Accounting, (12), 25-30.

Wei, W. (2011). Listed Companies share ownership and tax evasion. Macroeconomics, (1), 41-49.

Xianzhong, S. (2001). Correlation analysis of capital structure and tax. Journal of Jinan University (Philosophy \& Social Science Edition), 23(3), 71-77.

Xinhao, H. (2017).Tax policy, corporate earnings and manufacturing the actual tax rate difference. Finance and Accounting for International Commerce, (5), 44-49. 
Zhaoguo, Z., Baohong, Z., \& Ming, L. (2015).Corporate Governance, Tax Evasion, and Cash Holding Value: Empirical Evidence from Listed Companies in China. Nankai Business Review, 18(1), 15-24.

Zhijin, T., \& Kelong, H. (2015).Tax Avoidance, Financing Cost and Capital Allocation Efficiency of Enterprises: Based on the Data of Listed Companies in China. Journal of Zhongnan University of Economics and Law, (6), 74-81.

\section{Copyrights}

Copyright for this article is retained by the author(s), with first publication rights granted to the journal.

This is an open-access article distributed under the terms and conditions of the Creative Commons Attribution license (http://creativecommons.org/licenses/by/4.0/). 